\title{
From Paper to Screen: Encouraging Theory of Sociology through Sosiopedia by Heutagogy Approach
}

\author{
https://doi.org/10.3991/ijim.v15i01.14357 \\ Luhung Achmad Perguna, Idris $\left.{ }^{(}\right)$, Ahmad Arif Widianto \\ Universitas Negeri Malang, Malang, Indonesia \\ idris.fis@um.ac.id
}

\begin{abstract}
The advance of increasingly sophisticated technology, in the industrial revolution 4.0 era, led to the patterns of digital economy, artificial intelligence, big data, and robotic, referred as the phenomenon of disruptive innovation. This change was addressed by the University in how the learning process was carried out and how students learned. This study aims to develop a mobile learning application "Sosiopedia", which tries to offer a fundamental change in the process of learning paper to the screen, smart phones. The heutagogy approach was chosen to provide easy access to various information indirectly (asynchronous). This approach offers freedom for learners to determine by themselves the way how they learn. Meanwhile, for the development method, the research and development (R\&D) was used along with the Define, Design, Develop, and Disseminate model or 4D. Furthermore, sociological theory was chosen as the material in this development. Media and material validation in this research showed that product development was excellent and worth proving. In addition, Sosiopedia developed encourage student to motivate in learning sociology rather than in conventional approach.
\end{abstract}

Keywords - Sociological theory, heutagogy approach, industrial revolution, mobile learning, Sosiopedia

\section{Introduction}

Information technology has evolved and advanced rapidly in recent decades. Humans in life, work, and learning, have also significantly changed [1]-[5]. In addition, this progress is undeniably also caused by the era of the Internet of Thing [6] which gives opportunities to the public for wide access. [7]. The Internet of things has transformed digital life in all aspects and is considered as one of many important advancements in the industrial revolution era of this century. [8], [9]. Industrial Revolution 4.0 has also spawned new technologies namely artificial intelligence, cloud, virtual reality, and augmented reality, which has been widely used in instructional media.

The existence of online learning media has disrupted traditional paradigm learning in the classroom. [10]. This shows the demands of information technology media usage are inevitable. Various smart phone-based applications have begun to be integrated with 
today's online learning. Through these various applications, each material can be accessed easily without space and time. Therefore, the development of instructional media as part of the current Education process, requires innovation that is in accordance with the needs of students.

The great transformation with digitalization in all facets of life becomes a necessity [8], [9]. By revolutionary changes, especially in the technological advancement, it would change the way people live, work, relate to one another, and including how they learn. Finally, online-based learning is a demand that must be fulfilled because more and more people are literate and have internet accessibility. This is today's challenge with regard to the development of adaptive learning technologies related to millennial culture. Therefore, efforts to establish learning not only require the importance of the material. Through the development of mobile applications, the innovative creative work of learning can be encouraged.[11]-[14]. Innovative creative work in learning needs to be encouraged, through the development of mobile applications.

One effort to improve learning is by increasing the effectiveness of the use of instructional media. Arsyad [15] describes an effort to increase the effectiveness of the implementation of instructional media by increasing the teacher's proficiency in using instructional media [16]. The same thing was expressed by Bahri [17], an educator must have a variety of skills that support his ability to teach. One of these skills is how an educator can utilize learning media. Educators must be able to explain the subject to be taught to students by utilizing the learning media properly and correctly [18].

Learning media is a factor that can motivate and encourage students in implementing learning to achieve its uttermost outcomes [19], [20]. Learning media is a device that is physically utilized by educators and students in teaching and learning activities so that social interactions are formed which give rise to the curiosity of students to further enhance learning achievement [21]. In addition, the effectiveness of instructional media usage can be done by improving educators skills in mastering the instructional media as well as students acceptance in the learning media [20], [22]-[25]. Educators can develop learning strategies that are not just conveying information, but rather triggering students to learn to utilize learning media [26]-[28]. Thus, students will get a positive impact from the use of instructional media.

It is undeniable that students now cannot escape from the device. More than 93 million people in Indonesia and will continue to grow are internet users and around 71 million have smart phones. They tend to be connected with digital media. Most young people like to connect and communicate, and like to change. Moreover, technology that has succeeded in developing and changing in a way that is contrary to what is expected, is at a higher speed than is changing human beings themselves. The ambiguous and complex nature inherent in this technology shows its confirmed manifestation. This trait is increasing when faced with two clearly distinct generations. There are clear stuttering and some are successfully combined. These two generations were brought together in one era of big data, namely the generation of paper (digital immigrants) and the generation of digital (original digital) that was born with all of its automation [29], [30]. This two-generation meeting transformed this development into an educational setting in Indonesia. This must be addressed also by Higher Education including at the lowest level in the Department. 
Sosiopedia is an application that will be the answer in the midst of the minimization, even there is no application in mobile phones related to the Theory of Sociology. Students participate in discussing and solving theories in a variety of ways, through books, lecturers, or search engines. The book path is a path that is rarely chosen by students because of the level of difficulty when it requires high levels of concentration. Lectures from lecturers and through search engines are more often chosen by students and in accordance with the characteristics of students who always like instant things, and like to be placed on their zones, and fragile or known as the strawberry generation [31].

With the Sosiopedia application, it is expected to be an answer for millennial students belonging to the strawberry generation to make it easier for them to understand, obtain and explore knowledge about sociology theory. This ease will be raised through features such as pictures, materials, evaluations, and other visualizations which are also expected to make everyone feel at home. It is hoped that this application will inspire, help and also benefit many people, especially in sociology theory.

Sosiopedia was born and is expected to be an answer in the learning needs of higher education institutions especially those who want to wrestle, get to know and understand the theories of sociology, primarily classical sociology. Not only sociology figures but also sociology questions and also difficult words found in sociology terms. The products that will be produced are Sosiopedia products that are accessible to the public especially to those who want to learn Sociology promptly, accurately, and affordable price and wonderfully. This application will provide active and collaborative interactions. This means that students will build a spirit of learning together with other learners through the evaluations presented. Understanding of students is evaluated through evaluations provided by this application which in turn will build a spirit of coopetition and competition at other times.

\section{$2 \quad$ Literature Review}

Mobile Technologies usage continues to increase in all fields. In the economic field, Financial Technology has emerged, the world of banking has developed Mobile Banking, including education through Mobile Learning [32]-[34]. The industrial revolution, disruption, and pandemic require online learning, one of which is through the use of mobile technologies as learning media [35]-[39]. Some research and development on mobile learning has been carried out by academics such as the Mlearning model, design, application, effectiveness and current usage trends. [40] - [43]. Learning through mobile learning allows students to get learning materials more flexibly at any time anywhere by eliminating geographical boundaries [44], [45]. There are several characteristics of mobile learning which include its ever present, mobile tools portability, blended, privacy, interactive, collaborative, and immediate information [34], [46]-[48]. With these unique characteristics, mobile learning is in great demand by students who are part of the digital native. Mobile learning also has challenges, namely differences in mobile platforms (Android, IOS) and hardware; wireless network (geographical structure) and accessibility. Gradually, the scope of 
learning began to move from conventional and web based (e-learning) to mobile learning. This evolutionary migration must be able to be answered by education stakeholders to present applications that can answer existing challenges. Unfortunately, there are not many mobile learning applications, even though their presence is needed especially in the midst of a pandemic [34], [49]. The adoption as well as diffusion of mobile learning application usage in higher education are still rarely explored. and diffusion of mobile learning applications in higher education are still rarely explored.

\section{$3 \quad$ Methods}

Application-based media development requires precise and measurable methods to be used. The development method is appropriate in answering this problem because it will develop a new product that is developing the "Sosiopedia" application. What is trying to be applied in the design of teaching materials development is to adopt teaching materials for the 4D model suggested by Sivasailam Thiagarajan, Dorothy S. Semmel, and Melvyn I. Semmel [50]. The 4D model refers to the adaptation of four development stages which are Define (-ing), Design (-ing), Develop (-ing), and Disseminate (ing). But in this application development activity a modification was made in the 4-D model with the 4-P model which also consisted of four stages, namely pre-production, production, post production, and product publication (see figure 1). This stage is an inseparable part of one another and is interconnected even though it is flexible. This means that if the first stage has not been completed then it will not be able to go to the next stage. if there are deficiencies in the previous stage, it must return to the stage that has not been successfully passed.

\begin{tabular}{|c|c|c|c|}
\hline Pre Production & Production & $\begin{array}{c}\text { Post } \\
\text { Production }\end{array}$ & $\begin{array}{c}\text { Publication } \\
\text { Product }\end{array}$ \\
\hline $\begin{array}{l}\text { This stage is } \\
\text { identifying } \\
\text { theoretical } \\
\text { material and } \\
\text { preparing } \\
\text { questions as } \\
\text { well as setting } \\
\text { visualization } \\
\text { of applications }\end{array}$ & $\begin{array}{l}\text { This stage } \\
\text { focuses on the } \\
\text { design and } \\
\text { process of } \\
\text { developing an } \\
\text { application } \\
\text { with its } \\
\text { features } \\
\text { including } \\
\text { layouting and } \\
\text { editing }\end{array}$ & $\begin{array}{l}\text { Before } \\
\text { publishing, the } \\
\text { expert } \\
\text { judgment stage } \\
\text { both in terms } \\
\text { of content and } \\
\text { application } \\
\text { settings is } \\
\text { sought for } \\
\text { debugging. At } \\
\text { the same time } \\
\text { a trial is } \\
\text { feasiblely } \\
\text { performed on } \\
\text { users. }\end{array}$ & $\begin{array}{l}\text { After } \\
\text { proofreading } \\
\text { and refinement } \\
\text { of expert } \\
\text { input, the next } \\
\text { step is } \\
\text { launching this } \\
\text { application to } \\
\text { be used by } \\
\text { students to } \\
\text { acquire and } \\
\text { refine } \\
\text { knowledge } \\
\text { through the } \\
\text { sociopedia }\end{array}$ \\
\hline
\end{tabular}

Fig. 1. . The stages of application development 


\subsection{Pre-production stage}

Ingenious planning is the beginning of success. Learning innovation through the mobile application platform is carried out with carefully. The identification and analysis of requirements needed including the objectives achieved in developing this application were formulated at the outset. Objectives are important because they are related to what the application will be like. In another sense, this stage is also often referred to as needs analysis which at the same time also prepares the necessary visualizations of the images, photos and symbols needed.

\subsection{Production stage}

At this stage the focus is on making and designing designs to further enter the manufacturing stage. Lay outing and editing of the application that will be uploaded to the play store. The layout and design process, including the collection of material to be uploaded, is also prepared.

\subsection{Post production}

The main activity at this stage is expert judgment after the application. At the same time, the product trials were also conducted with a minimal number of students. Suggestions, proposals and criticisms from experts are considered in this activity. They did a review of this application with the format provided. This activity was also packaged in a Focus Group Discussion held at MAN 1 Kota Batu and also at the Co Working Space in Rungkut Surabaya. After the revision of the input from the expert both in terms of content and application, the last stage is the product is ready to be published/ launched. The last stage is the publication product. At this stage the application is ready to be used and included in SIPEJAR and implemented in the classroom.

One of the strengths of the application is that users will be able to access 24 hours as long as they carry and upload the application. This application can be used offline after being downloaded offline. In this application, in addition to focusing on the material presented, it also tries to display supporting visualizations so that users will not be bored and continue to be interested in using it. Applications with good visuals and structured material will help the audience in staying focused and continued to stay tune with the application. Therefore, a valiant effort is required in making the application to provide the best visual and sound effects.

\section{$4 \quad$ Result and Discussion}

\subsection{Product development process}

The development of this application requires considerable time and process. There are three main things in making this application including, first, the development of 
material (content) in sociology, choosing what is important and relevant for publication. The second is related to the application itself (technical aspects) which requires a third party in the process of completion for more optimal and satisfying results. Third is the visual aspect (ranging from logo design, layout, images and coloring from the Sosiopedia application). These three things are done together and simultaneously. Coordination is carried out continuously in order to produce applications that are feasible and certainly beneficial to the audience. If the maker omitted this step, there is a possibility that the application will not lifelong like an ivory tower. Thus, a valiant effort is required in making the application to provide the best visual and sound effects. (see figure 2).

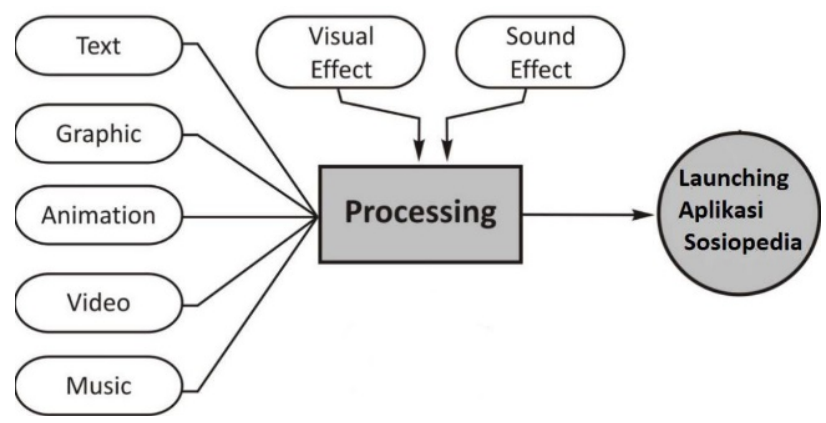

Fig. 2. The process of product development

This learning innovation product is the first in sociology (at least based on team searches and also from the Indonesian Sociology Study Program Association) and is arguably the main pioneer. However, there are similar application products that focus more on questions for high school or equivalent students. There is no mobile application for students primarily in sociology theory.

Table 1. Product and its features

\begin{tabular}{|c|l|l|}
\hline No. & \multicolumn{1}{|c|}{ Categories } & \multicolumn{1}{c|}{ Features } \\
\hline 1 & SosioKamus & $\begin{array}{l}\text { Explanation of difficult words found in sociological terms such as gemeinschaft, } \\
\text { gesellschafts and so on. This explanation is important in order to make it easier for } \\
\text { people to study sociology. }\end{array}$ \\
\hline 2 & SosioInfo & $\begin{array}{l}\text { Information, news, announcements are alternative features provided to users as } \\
\text { supporting insights, including as a way to produce monetizing through } \\
\text { advertisements and shared information. }\end{array}$ \\
\hline 3 & SosioTokoh & $\begin{array}{l}\text { This feature focuses on explaining the conceptions and theories of prominent } \\
\text { sociology figures such as Ibn Khaldun, Max Webber, Karl Marx, Emile Durkheim } \\
\text { and others. Visualization is also presented to users. }\end{array}$ \\
\hline & $\begin{array}{l}\text { Here, users are spoiled with multiple choice evaluation questions ranging from Low } \\
\text { Order Thinking Skills to High Order Thinking Skill levels. Users are also given a } \\
\text { choice of categorization in accordance with the 2013 curriculum for high school / } \\
\text { equivalent. }\end{array}$ \\
\hline
\end{tabular}

These four features are complementary and complementary, including updating SosioInfo, which requires updating. The figures can be seen as follow: 

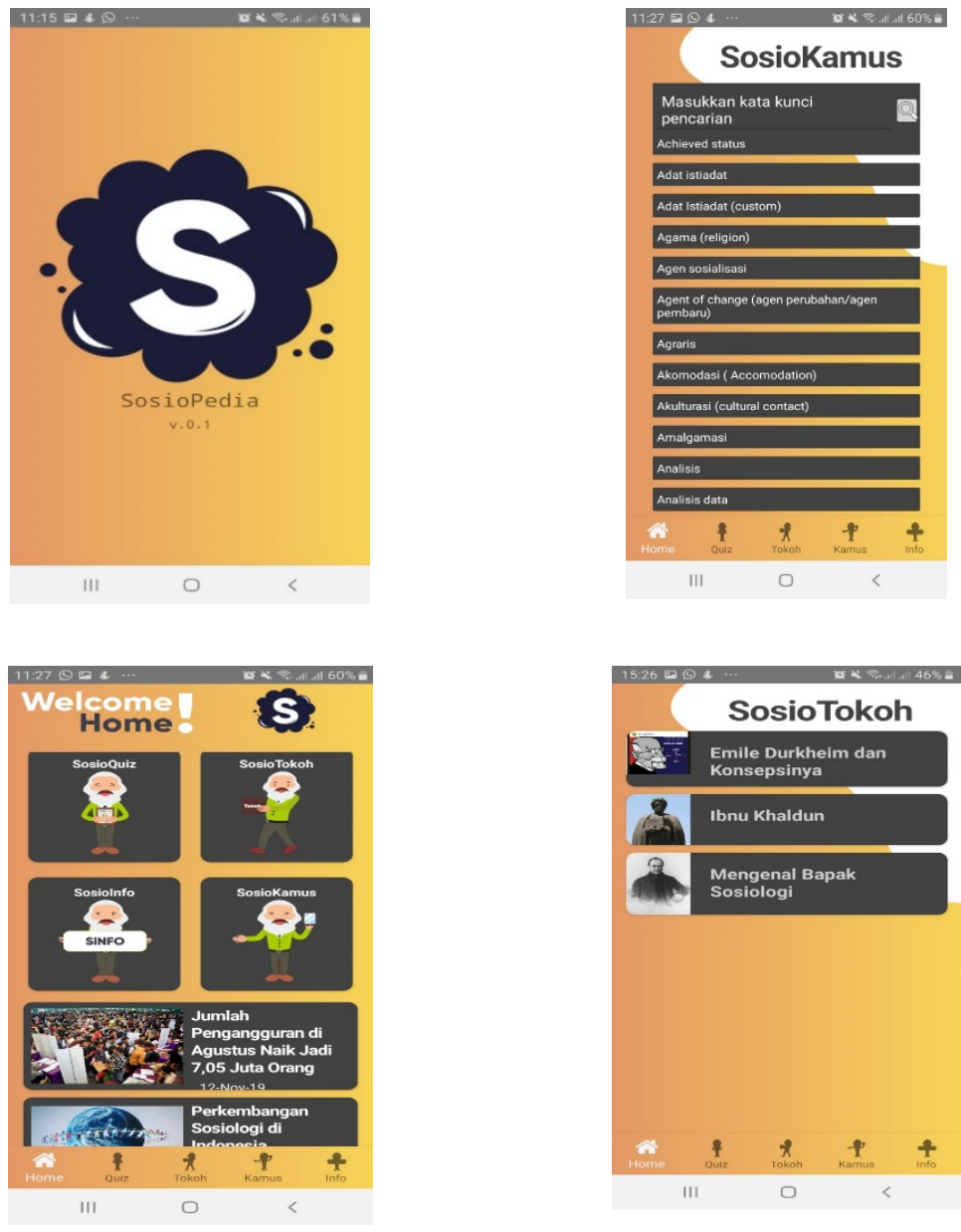

Fig. 3. The "Sosiopedia" display

\subsection{Product implementation}

To test the validity and legibility of a product, a trial and product validation is absolutely necessary. Material validation by using certain instruments is an assessment of the quality of the material developed whether it is in accordance with the needs and components of existing learning tools. The instrument used in this application is aimed at assessing the appropriateness of visualization and also the material written in this application. There are two data used, quantitative data and qualitative data. Quantitative data compiled in the form of lift used is a multilevel scale, which is a question followed by columns indicating levels, for example from strongly agreeing to strongly disagreeing (Arikunto, S. 2010). Qualitative data was also collected through unstructured interviews with experts both in terms of material and its application. 
The validation was carried out by two material and media experts. The experts will provide early evaluation and inputs on the product, which will be revised and refined upon the development result of this learning innovation. Sabil Amir, M.Sc, a Sociology Teacher at MAN 1 Batu City is the material validator. He was once appointed as a writer about the National Level UNBK, and at the same time he was the Secretary of the MGMP of Sociology MAN in East Java Province. As such, Mr Amir is eligible in providing a material evaluation of the application development product. As for learning media validator, Saipul Annas was appointed. He is one of many competent IT expert consultants. Almost all websites belonging to one large institution he has managed until now. The validation by both material and media experts will provide recommendations over the product's feasibility to be used as the main learning content in Sociology Theory 1 material in the Sociology Education Study Program.

The result shows that the packaged media and materials are under both material and instructional media standards as an application. However, there are several assessment indicators to be noted. Improvement suggestions for the final product development are also given before product publication. Some of the suggestions are as follows: First suggestion was regarding the material. There are three points to take into account, namely the contents of the images strived to be relevant, harmony in the layout and also categorized to make it easier for users to find what is needed, both from the questions and sociology figures. The second suggestion was the media. There points were made by the expert team which includes pictures that need its characters name, the usage of clear images, and harmony in layout.

The testing phase comes next after expert validation. It h involves 35 students of the Sociology Education study program. The tested application is a feature on SosioInfo, SosioKamus, SosioTokoh, and SosioQuiz. Of the four features, the students have assessed the appropriateness of this Sosiopedia application. The testing results evaluation can be found as follows:

Table 2. Student's suggestions

\begin{tabular}{|c|l|l|}
\hline No. & \multicolumn{1}{|c|}{ Categories } & \multicolumn{1}{c|}{ Suggestions } \\
\hline 1. & SosioQuiz & Need to categorize the questions \\
\hline 2. & SosioTokoh & Need to add a few more figures \\
\hline 3. & SosioKamus & Need to add the Search feature \\
\hline 4. & SosioInfo & Need to be given additional images in the feature \\
\hline 5. & Umum & There are descriptions on the figures \\
\hline
\end{tabular}

Based on the results of this initial validation, the team then continued to improve the suggestions and input provided by the experts. From the overall inputs, this application obtained a percentage value of $87.66 \%$. What can be concluded is that in general the multimedia developed has been valid and deserves to be tested even ready to be published.

For decades, many studies have noted the importance of using technology such as mobile devices in learning within the education context. [13], [16], [51]. The main focus of this research is to develop a mobile learning application called Sosiopedia which is 
intended to provide accessible learning for students without time and space boundaries [4], [52]-[54]. In addition, students' implementation results found that effectiveness of using applications in the learning process has provided new and limitless experiences for students to obtain extensive sources of information for the development of their knowledge.

\section{Conclusion}

This learning innovation is designed to introduce the public to and broaden the theory of sociology and sociology. There are four features in this application, the first is SocioKamus which contains difficult words or terms in sociology. The second is SosioQuiz which contains questions in sociology based on the Basic Competencies that exist in SMA/ MA (senior high school) based on the 2013 curriculum. The third is SosioTokoh which contains concepts introduced by sociology figures. The last one is SosioInfo which contains news about sociology. These four features are summarized in an application called Sosiopedia.

The results of this development show students' likeliness towards innovation. This means, according to class observations results averagely the student spent at least 3 hours on a mobile phone. Thus, the learning approach and development should be directed towards millennial development rather than traditional conventional lectures while still being student centered. Introductory courses in sociology must contribute enough space for students' sociological imagination development. The next research and development can be focused on more materials or, even, more videos, integrated in the application to embed additional values for users.

\section{References}

[1] I. U. Khan, Z. Hameed, Y. Yu, T. Islam, Z. Sheikh, and S. U. Khan, "Predicting the acceptance of MOOCs in a developing country: Application of task-technology fit model, social motivation, and self-determination theory," Telemat. Inform., vol. 35, no. 4, pp. 964 978, Jul. 2018, https://doi.org/10.1016/j.tele.2017.09.009

[2] B. Kurniawan, I. Idris, A. Purnomo, A. Wiradimadja, and S. Sukamto, "Using Broadcasting Learning Design to Enhance Student's Experiential Skill," Int. J. Emerg. Technol. Learn. IJET, vol. 14, no. 16, pp. 172-180, Aug. 2019, https://doi.org/10.3991/ijet. v14i16.10652

[3] K. H. Lau, T. Lam, B. H. Kam, M. Nkhoma, J. Richardson, and S. Thomas, "The role of textbook learning resources in e-learning: A taxonomic study," Comput. Educ., vol. 118, pp. 10-24, Mar. 2018, https://doi.org/10.1016/j.compedu.2017.11.005

[4] N. Ratnawati and I. Idris, "Improving Student Capabilities through Research-Based Learning Innovation on E-Learning System," Int. J. Emerg. Technol. Learn. IJET, vol. 15, no. 04, pp. 195-205, Feb. 2020, https://doi.org/10.3991/ijet.v15i04.11820

[5] W. D. Sulistyo, U. Nafi' ah, and I. Idris, "The Development of E-PAS Based on Massive Open Online Courses (MOOC) on Local History Materials," Int. J. Emerg. Technol. Learn. IJET, vol. 14, no. 09, p. 119, May 2019, https://doi.org/10.3991/ijet.v14i09.10143 
[6] K.-S. Hong, A. A. Ridzuan, and M.-K. Kuek, "Students' attitudes toward the use of the Internet for learning: A study at a university in Malaysia," J. Educ. Technol. Soc., vol. 6, no. 2, pp. 45-49, 2019.

[7] D. Gibson, T. Broadley, J. Downie, and P. Wallet, "Evolving Learning Paradigms: ReSetting Baselines and Collection Methods of Information and Communication Technology in Education Statistics," Educ. Technol. Soc., vol. 21, no. 2, pp. 62-73, 2018.

[8] D. Lupton, Digital sociology. UK: Routledge, 2014.

[9] K. P. Polanyi, The great transformation:(The political and economic origin of our time). US.: Beacon Press, 1957.

[10] Y. Jung and J. Lee, "Learning Engagement and Persistence in Massive Open Online Courses (MOOCS)," Comput. Educ., vol. 122, pp. 9-22, Jul. 2018, https://doi.org/10.1016/ j.compedu.2018.02.013

[11] S. Papadakis and M. Kalogiannakis, Mobile Learning Applications in Early Childhood Education. IGI Global, 2019.

[12] M. Kalogiannakis and S. Papadakis, "Evaluating pre-service kindergarten teachers' intention to adopt and use tablets into teaching practice for natural sciences," Int. J. Mob. Learn. Organ., vol. 13, no. 1, pp. 113-127, 2019, https://doi.org/10.1504/ijmlo. 2019.10016617

[13] S. Papadakis, J. Vaiopoulou, M. Kalogiannakis, and D. Stamovlasis, "Developing and Exploring an Evaluation Tool for Educational Apps (E.T.E.A.) Targeting Kindergarten Children," Sustainability, vol. 12, no. 10, p. 4201, May 2020, https://doi.org/10.3390/ su12104201.

[14] A. Widianto, J. Purwasih, and L. Perguna, "Promoting Social Cohesion: The Development of E-Learning Management System Materials through Life Based Learning for Sociology of Religion Course," Int. J. Emerg. Technol. Learn. IJET, vol. 15, no. 07, pp. 162-170, 2020, https://doi.org/10.3991/ijet.v15i07.13339

[15] A. Arsyad, Media Pembelajaran. Jakarta: Rajawali Pers, 2013.

[16] S. Papadakis, "Evaluating pre-service teachers' acceptance of mobile devices with regards to their age and gender: a case study in Greece," Int. J. Mob. Learn. Organ., vol. 12, no. 4, pp. 336-352, 2018, https://doi.org/10.1504/ijmlo.2018.10013372

[17] S. Bahri, Strategi Belajar Mengajar. Jakarta: PT Rhineka Cipta, 2006.

[18] U. Usman, Menjadi Guru Profesional. Bandung: Remaja Rosdakarya, 2006.

[19] S. A. Ariffin, S. F. Sidek, and M. F. H. Mutalib, "A Preliminary Investigation of Malaysian Student's Daily Use of Mobile Devices as Potential Tools for STEM in a Local University Context," Int. J. Interact. Mob. Technol. IJIM, vol. 12, no. 2, pp. 80-91, Mar. 2018, https://doi.org/10.3991/ijim.v12i2.8015

[20] E. Issaramanoros, J. Khlaisang, and P. Pugsee, “Auto Mechanic Students' Perceptions and Readiness toward Mobile Learning in Thailand," Int. J. Interact. Mob. Technol. IJIM, vol. 12, no. 5, pp. 28-42, Sep. 2018, https://doi.org/10.3991/ijim.v12i5.8906

[21] Y. Zidoun, R. Dehbi, M. Talea, and F.-Z. El Arroum, "Designing a Theoretical Integration Framework for Mobile Learning," Int. J. Interact. Mob. Technol. IJIM, vol. 13, no. 12, pp. 152-170, Dec. 2019, https://doi.org/10.3991/ijim.v13i12.10841

[22] M. T. Alshurideh, S. A. Salloum, B. Al Kurdi, A. Abdel Monem, and K. Shaalan, "Understanding the Quality Determinants that Influence the Intention to Use the Mobile Learning Platforms: A Practical Study,” Int. J. Interact. Mob. Technol. IJIM, vol. 13, no. 11, pp. 157-183, Nov. 2019, https://doi.org/10.3991/ijim.v13i11.10300

[23] F. D. Deris and N. S. A. Shukor, "Vocabulary Learning Through Mobile Apps: A Phenomenological Inquiry of Student Acceptance and Desired Apps Features," Int. J. 
Interact. Mob. Technol. IJIM, vol. 13, no. 07, pp. 129-139, Jul. 2019, https://doi.org/10. 3991/ijim.v13i07.10845

[24] H.-J. Kim and J.-Y. Rha, "Predicting the Drivers of the Intention to Use Mobile Learning in South Korea," Int. J. Interact. Mob. Technol. IJIM, vol. 12, no. 1, pp. 116-132, Jan. 2018, https://doi.org/10.3991/ijim.v12i1.7688

[25] K. Y. Qudah, J. A. Hussain, and R. Al Matari, "Students' Attitudes in Colleges of Education at the Jordanian Universities towards Mobile Phone Usage in University Education," Int. J. Interact. Mob. Technol. IJIM, vol. 7, no. 2, pp. 19-28, Apr. 2013, https://doi.org/10. 3991/ijim.v7i2.2286

[26] C. Abdul Talib, H. Aliyu, A. M. Abdul Malik, K. Hooi Siang, I. Novopashenny, and M. Ali, "Sakai: A Mobile Learning Platform," Int. J. Interact. Mob. Technol. IJIM, vol. 13, no. 11, pp. 95-109, Nov. 2019, https://doi.org/10.3991/ijim.v13i11.10800

[27] A. Bhattacherjee and M. Harris, "Individual Adaptation of Information Technology," J. Comput. Inf. Syst., vol. 50, no. 1, pp. 37-45, 2009, doi: 10.1080/08874417.2009.11645360.

[28] J. Eppard, Z. Hojeij, P. Ozdemir-Ayber, M. Rodjan-Helder, and S. Baroudi, "Using Mobile Learning Tools in Higher Education: A UAE Case," Int. J. Interact. Mob. Technol. IJIM, vol. 13, no. 11, pp. 51-69, Nov. 2019, https://doi.org/10.3991/ijim.v13i11.10823

[29] M. Prensky, "Digital natives, digital immigrants' part 1," Horiz., vol. 9, no. 5, pp. 1-6, 2001.

[30] Q. E. Wang, M. D. Myers, and D. Sundaram, "Digital natives and digital immigrants," Bus. Inf. Syst. Eng., vol. 5, no. 6, pp. 409-419, 2006. https://doi.org/10.1007/s12599-013-0296y

[31] R. Khasali, Mengubah Genarasi Rapuh menjadi Generasi Tangguh "Strawberry Genartion." Jakarta: Mizan Media Utama, 2017.

[32] K. F. Hew, "Use of audio podcast in K-12 and higher education: A review of research topics and methodologies," Educ. Technol. Res. Dev., vol. 57, no. 3, pp. 333-357, 2009. https://doi.org/10.1007/s11423-008-9108-3

[33] S. Lakhal, H. Khechine, and D. Pascot, "Evaluation of the effectiveness of podcasting in teaching and learning," in E-Learn: World Conference on E-Learning in Corporate, Government, Healthcare, and Higher Education, 2007, pp. 6181-6188.

[34] F. Ozdamli and N. Cavus, "Basic elements and characteristics of mobile learning," ProcediaSoc. Behav. Sci., vol. 28, pp. 937-942, 2011. https://doi.org/10.1016/j.sbspro. $\underline{2011.11 .173}$

[35] G. Baskoro, "Challenges and Opportunities of Higher Education Institution in the disruption era towards Education 4.0," 2018.

[36] R. E. Ferdig, E. Baumgartner, R. Hartshorne, R. Kaplan-Rakowski, and C. Mouza, "Teaching, technology, and teacher education during the covid-19 pandemic: Stories from the field," Waynesville NC USA Assoc. Adv. Computer. Educ. AACE, 2020.

[37] P. Hayes, D. Joyce, and P. Pathak, "Ubiquitous learning-an application of mobile technology in education," in Ed Media+ Innovate Learning, 2004, pp. 1811-1816.

[38] K. T. Martono and O. D. Nurhayati, "Implementation of android based mobile Learning application as a flexible learning Media,” Int. J. Computer. Sci. Issues IJCSI, vol. 11, no. 3, p. 168, 2014.

[39] S. Zizek, PANDEMIC! Covid-19 Shakes the World. John Wiley \& Sons, 2020.

[40] A. Barker, G. Krull, and B. Mallinson, "A Proposed Theoretical Model for M-Learning Adoption in Developing Countries," in m-Learn 2005-4th World conference on m-Learning Cape Town," 2009.

[41] D. Parsons, H. Ryu, and M. Cranshaw, "A study of design requirements for mobile learning environments," in Sixth IEEE International Conference on Advanced Learning 
Technologies (ICALT'06), 2006, pp. 96-100. https://doi.org/10.1109/icalt.2006. 1652376

[42] S. K. Sharma and F. L. Kitchens, "Web services architecture for m-learning.," Electron. J. E-Learn., vol. 2, no. 1, pp. 203-216, 2004.

[43] R. Y.-L. Ting, "Mobile learning: Current trend and future challenges," in Fifth IEEE International Conference on Advanced Learning Technologies (ICALT'05), 2005, pp. 603607. https://doi.org/10.1109/icalt.2005.202

[44] Y.-F. Lan and Y.-S. Sie, "Using RSS to support mobile learning based on media richness theory," Computer. Educ., vol. 55, no. 2, pp. 723-732, 2010. https://doi.org/10.1016/ j.compedu.2010.03.005

[45] M. O'Connell, R. Benson, and G. Samarawickrema, "Professional development for professional developers: who's learning about e-learning from whom?" in Who's learning? Whose technology? The 23rd annual conference of the Australasian Society of Computers in Learning in Tertiary Education, 2006, pp. 599-602.

[46] N. Cavus and D. Ibrahim, "m-Learning: An experiment in using SMS to support learning new English language words," Br. J. Educ. Technol., vol. 40, no. 1, pp. 78-91, 2009. https://doi.org/10.1111/j.1467-8535.2007.00801.x

[47] H. Uzunboylu, N. Cavus, and E. Ercag, "Using mobile learning to increase environmental awareness," Comput. Educ., vol. 52, no. 2, pp. 381-389, 2009. https://doi.org/10.1016/ j.compedu.2008.09.008

[48] M. Virvou and E. Alepis, "Mobile educational features in authoring tools for personalised tutoring," Comput. Educ., vol. 44, no. 1, pp. 53-68, 2005. https://doi.org/10.1016/ j.compedu. 2003.12.020

[49] A. Naciri, M. A. Baba, A. Achbani, and A. Kharbach, "Mobile learning in Higher education: Unavoidable alternative during COVID-19," Aquademia, vol. 4, no. 1, p. ep20016, 2020. https://doi.org/10.29333/aquademia/8227

[50] S. Thiagarajan, DS. Semmel, and MI. Semmel, Instructional Development for Training Teacher of Exceptional Children. Minnesota: Indiana University, 1974.

[51] P. Dorouka, S. Papadakis, and M. Kalogiannakis, "Tablets and apps for promoting robotics, mathematics, STEM education and literacy in early childhood education,” Int. J. Mob. Learn. Organ. IJMLO, vol. 14, no. 2, pp. 255-274, 2020. https://doi.org/10.1504/ ijmlo.2020.10026334

[52] L. A. Perguna, I. Idris, and I. Irawan, "From Content to Context: Understanding Introduction to Sociology through MOOC," Int. J. Emerg. Technol. Learn. IJET, vol. 15, no. 07, pp. 188195, Apr. 2020, https://doi.org/10.3991/ijet.v15i07.13467

[53] B. Kurniawan, A. Purnomo, I. Idris, K. R. Adi, and I. D. P. Eskassnanda, "Using SPADA Brightspace to Enhance Pedagogical Skills in Teacher Professional Program," Int. J. Emerg. Technol. Learn. IJET, vol. 15, no. 07, pp. 180-187, Apr. 2020, https://doi.org/10.3991 /ijet.v15i07.13371

[54] N. Wahyuningtyas and I. Idris, "Increasing Geographic Literacy through the Development of Computer Supported Collaborative Learning,” Int. J. Emerge. Technol. Learn. IJET, vol. 15, no. 07, pp. 74-85, Apr. 2020, https://doi.org/10.3991/ijet.v15i07.13255

\section{$7 \quad$ Authors}

Luhung Achmad Perguna, is member of lecturer in Department of Sociology, Faculty of Social Sciences, Universitas Negeri Malang. His main research interest is sociological studies and learning resources media. Email: luhung.fis@um.ac.id 
Idris is one of the lecturers in Social Studies Program, Faculty of Social Science, Universitas Negeri Malang. $\mathrm{He}$ is interested in learning innovation. Email: idris.fis@um.ac.id

Ahmad Arif Widianto is an Indonesian Sociological Education, one of the lecturers in Department of Sociology, Faculty of Social Science, Universitas Negeri Malang. He is interested in educational sociology and learning media. Email: $\underline{\text { ahmad.arif.fis@um.ac.id }}$

Article submitted 2020-03-23. Resubmitted 2020-10-14. Final acceptance 2020-10-14. Final version published as submitted by the authors. 